Gut, 1986, 27, 55-58

\title{
Effects of antimicrobial therapy on faecal bulking
}

\author{
A V KURPAD AND P S SHETTY \\ From the ICMR Nutrition Research Centre, Department of Physiology, St John's Medical College, \\ Bangalore, India
}

SUMMARY It has recently been postulated that dietary fibre acts as a substrate for colonic flora, and that the resultant microbial growth bulks the faeces. Antimicrobial therapy was used in this study to assess the effect of reduction in colonic microbial proliferation on faecal output in human subjects on a constant dietary fibre intake. Six healthy young male subjects were maintained on constant daily diets and metronidazole $(1 \mathrm{~g} /$ day $)$ and ampicillin $(1 \mathrm{~g} /$ day $)$ were administered in divided doses for one week after an initial baseline study period of two weeks. After antimicrobial therapy, mean faecal weights rose from $176.0 \pm 27.0 \mathrm{~g}$ to $348 \cdot 1 \pm 37.7 \mathrm{~g} /$ day. Faecal solids increased from $32 \cdot 9 \pm 4 \cdot 2 \mathrm{~g}$ to $46 \cdot 1 \pm 5 \cdot 8 \mathrm{~g} / \mathrm{day}$. Faecal neutral detergent fibre increased from $1.92 \pm 0.42 \mathrm{~g}$ to $15 \cdot 19 \pm 2.58 \mathrm{~g} /$ day. The mean transit times and mean daily faecal nitrogen remained the same, both before and after treatment. Substantial breakdown of dietary fibre occurs in the human colon which may decrease faecal bulk, suggesting that water holding by dietary fibre is probably of greater importance for faecal bulking.

Dietary fibre is an important constituent of the diet which affects large bowel function by causing an increased faecal output. ${ }^{1}$ An earlier hypothesis implied that fibre by resisting digestion, passes through the human gut and bulks the faeces by holding water within its cellular structure. ${ }^{2}$ The in vitro water holding ability of different fibres does not correlate with the effects the same fibre has on colonic function. ${ }^{3}$ A recent assessment of the microbial content of human faeces has indicated that bacteria represents a high proportion of faecal mass. ${ }^{4}$ Hence, it has been postulated that many types of fibre act as substrates for colonic flora and the resultant increased microbial growth bulks the faeces. ${ }^{5}$ Studies carried out by us have also tended to support the latter hypothesis as restriction of protein in the diet which limits nitrogen availability influences bacterial growth and reduces faecal output. ${ }^{6}$ Because a part of the fibre in the diet bulks the faeces by enhancing microbial proliferation, any factor that affects microbial growth should alter the degree of faecal bulking achieved and hence the transit. Therefore, we designed this study to look at the effect of reduction in microbial numbers by antimicrobial therapy on faecal output in human subjects on a constant dietary fibre intake.

Address for correspondence: Dr P S Shetty, Department of Physiology, St John's Medical College, Bangalore-560 034, India.

Received for publication 9 April 1985

\section{Methods}

SUBJECTS

Six, young, healthy male subjects, aged between 18 and 25 years, were admitted to a metabolic facility and maintained on controlled diets for 24 days. All subjects had been screened for gastrointestinal disease, had been free of any illness for six months preceding the study, had no history suggestive of gastrointestinal dysfunction and stool examinations were negative for parasites.

\section{DIETS}

During the initial eight days, the subjects were equilibrated on individual diets, which were then kept constant throughout the rest of the study period. The diet provided a constant energy, constant protein, and constant dietary fibre intake per individual per day. This was confirmed by the subjects weighing their intake of food every day of the study period. Dietary intakes of the various constituents were assessed using food composition tables $^{78}$ and data on dietary fibre analysis of different foods. ${ }^{910}$

\section{ANTIMICROBIAL THERAPY}

One week after the initial eight day equilibration period - that is, on day 15 of the study period, all subjects received $1 \mathrm{~g} /$ day metronidazole in divided 
doses for one week until day 22 , of the study period. In addition ampicillin, $1 \mathrm{~g} /$ day was also administered for the same length of time, to reduce breakdown of metronidazole by aerobes. ${ }^{11}$

\section{TRANSIT TIME AND FAECAL WEIGHTS}

Intestinal transit time was continuously monitored after the initial eight day period, for two weeks. The continuous marker technique was used to determine the mean transit time (MTT). ${ }^{12}$ Complete faecal collections were made and the markers recovered; marker recovery in the faeces was $99.9 \%$ in all subjects. Faecal weights were recorded daily during the study period.

FAECAL SOLIDS AND FAECAL WATER

After recording faecal weights, the faeces collected over the last four days of the control period and the last four days of antimicrobial treatment were homogenised in deionised water. Aliquots of the samples were frozen and stored at $-20^{\circ} \mathrm{C}$ for further study. Faecal solids were estimated by drying the sample in a hot air oven to $105^{\circ} \mathrm{C}$ for 24 hours followed by repeated weighing to constant weight. Faecal water (\% moisture) was estimated using wet weight and dry weight of the sample.

NEUTRAL DETERGENT FIBRE (NDF) AND ASH The neutral detergent fibre in homogenised faeces was estimated using the method of Goering and Van Soest. ${ }^{13}$ The samples were refluxed with neutral detergent solution and filtered under vacuum. The filtrate was treated with acetone and dried in an oven at $105^{\circ} \mathrm{C}$ for 24 hours, followed by weighing of the hot sample. After extraction, this fibre was ashed at $550^{\circ} \mathrm{C}$ in a muffle furnace.

\section{FAECAL AND URINARY NITROGEN}

Nitrogen (N) estimation was carried out on each of the samples using the micro-Kjeldahl technique. ${ }^{14}$ The sample digested in concentrated $\mathrm{H}_{2} \mathrm{SO}_{4}$ was steam distilled and the effluent ammonia was trapped in boric acid and titrated against dilute $\mathrm{H}_{2} \mathrm{SO}_{4}$. The same procedure was followed for urinary $\mathrm{N}$ estimation, from stored aliquots of 24 hour urine collections made throughout the study period.

Ethical approval and informed consent was obtained for the study.

STATISTICAL ANALYSIS

Results are expressed as means plus or minus one standard error (mean \pm SEM). Statistical evaluation of data was done using Student's $t$ test and values were considered significant if $\mathrm{p}<0 \cdot 05$.

\section{Results}

\section{DIETARY CONSTITUENTS}

The daily intake of the various dietary constituents per day, during the study were as follows: energy intake: $2548 \pm 162 \mathrm{Kcal}(10 \cdot 8 \pm 0 \cdot 7 \mathrm{MJ})$; protein intake: $74.0 \pm 5.0 \mathrm{~g}$; fat intake: $90.6 \pm 2.8 \mathrm{~g}$; dietary fibre intake: $18 \cdot 3 \pm 1 \cdot 1 \mathrm{~g}$ (non-cellulosic polysaccharide $12.6 \pm 0.8 \mathrm{~g}$, cellulose $4.6 \pm 0.2 \mathrm{~g}$, lignin $1 \cdot 1 \pm 0.05 \mathrm{~g}$ ). Daily intake of egg, meat or fish, milk and milk products contributed to the protein and fat intake. While vegetables and fruits accounted for $36 \%$ of the daily fibre intake, cereals, and lentils (pulses) provided $41 \%$ and $12 \%$ respectively.

\section{FAECAL WEIGHTS}

After antimicrobial therapy, mean faecal weights over a week rose in all six subjects, from a mean daily output of $176.0 \pm 27.0 \mathrm{~g}$ (range 117.7 to $296.5 \mathrm{~g}$ per day) to $348 \cdot 1 \pm 37.7 \mathrm{~g}$ (range 250.0 to $490.8 \mathrm{~g}$ per day); a significant increase $(\mathrm{p}<0.001)$ of $198 \%$.

\section{TRANSIT TIMES}

Changes in transit times were not significant; the average transit time before treatment was $30 \cdot 3 \pm 3 \cdot 2$ $\mathrm{h}$ and after, was $32.8 \pm 4.3 \mathrm{~h}$. While an increased transit time was seen in three of the subjects, a decrease was seen in the rest.

\section{FAECAL SOLIDS AND WATER}

Faecal solids increased from $32.9 \pm 4.2 \mathrm{~g} /$ day to $46 \cdot 1 \pm 5 \cdot 8 \mathrm{~g} /$ day after treatment. The water content of the faeces increased from $123.5 \pm 30.8 \mathrm{~g} /$ day to $266.0 \pm 52.2 \mathrm{~g} /$ day and the percentage of moisture increased to $84 \cdot 1 \pm 0.9 \%$ after treatment, from a basal value of $77 \cdot 6 \pm 1 \cdot 4 \%$ (see Table).

Table Changes in transit time, faecal weight and faecal parameters after antimicrobial treatment

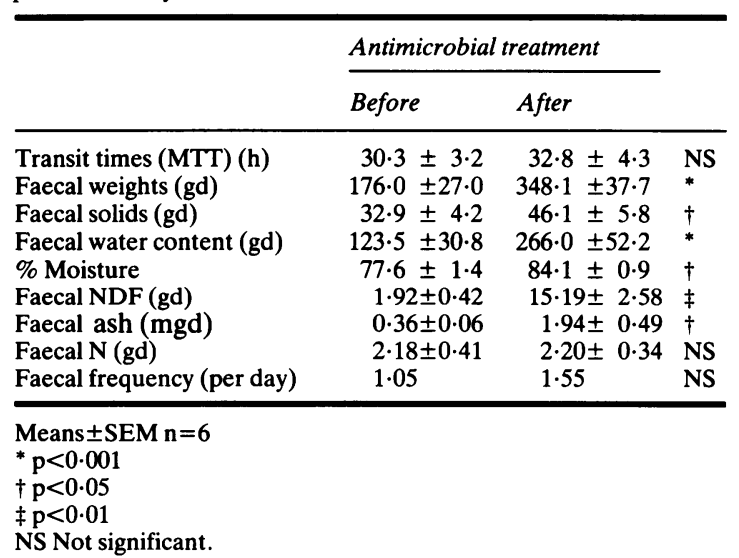


NDF AND ASH CONTENT

Faecal neutral detergent fibre rose from a pretreatment value of $1.92 \pm 0.42 \mathrm{~g} /$ day to $15 \cdot 19 \pm 2.58 \mathrm{~g} /$ day after treatment. This was also manifested as an observable increase in the visible fibre of the faeces. The percentage of neutral detergent fibre in the faecal solids rose form $7 \cdot 2 \%$ to $38 \%$. The ash content before treatment was $0.36 \pm 0.06 \mathrm{mg} /$ day and increased to $1.94 \pm 0.49 \mathrm{mg} /$ day after treatment.

\section{FAECAL AND URINARY NITROGEN}

Faecal nitrogen showed no significant change after antimicrobial treatment, being $2 \cdot 18 \pm 0.41 \mathrm{~g} /$ day before and $2.2 \pm 0.34 \mathrm{~g} /$ day after treatent. When considered as a percentage of total faecal mass, however, nitrogen content reduced from $1.33 \%$ to $0.70 \%$ after administration of antibiotics. There was no significant change in the daily urinary output and urinary nitrogen excretion before and after treatment.

\section{Discussion}

Dietary fibre is digested to variable degrees during its passage through the gut. ${ }^{15} 16$ The colonic microflora and the transit time are two host factors that affect the overall digestability of fibre. ${ }^{17}$ Anaerobes, a major constituent of colonic microbes ${ }^{11} 18$ digest and ferment fibre ${ }^{19}$ and hence administration of metronidazole which is particularly effective against anaerobes, ${ }^{20}$ has increased the neutral detergent fibre content of the faeces. This substantiates the fact that a large fraction of the dietary fibre is digested by the colonic microbial flora in man also. The microbial growth thus stimulated increases the bulk of colonic contents and the daily faecal output. ${ }^{5}$ Assuming that the contribution to faecal bulking by bacteria is the more usual mechanism in man, antimicrobial treatment should alter the faecal composition and bulk. The increase in faecal bulk on identical intakes of dietary fibre seen after antimicrobial treatment was probably the result of an increased quantity of undegraded fibre in the faeces, which, because of its water holding capacity, bulked the faeces. Faecal bulking due to water holding by undigested fibre seems to be the more effective mechanism than the contribution by an increased bacterial mass. The data of Stephen and Cummings ${ }^{5}$ also show that cereal fibre such as wheat, which is least degraded, contributed to faecal bulking much more than an equal quantity of degradable fibre such as cabbage which bulks the faeces by increasing bacterial mass.

The increase of neutral detergent fibre in the faeces after metronidazole and ampicillin when intake of fibre is unaltered suggests that bacterial degradation of fibre has possibly a negative role to play in faecal bulking, because faecal weights are much larger if colonic flora are prevented from digesting the available fibre. Faecal solids increased significantly after antimicrobial treatment; this is because of an increase in the neutral detergent fibre content of the faeces. Increase in dietary fibre intake increases faecal nitrogen as a result of an increased microbial cell output. ${ }^{21}$ Antimicrobial therapy need not result in a decrease in faecal nitrogen excretion because the increase in faecal bulk due to undegraded fibre is likely to increase the excretion of soluble non-bacterial forms of nitrogen in the faeces, as is seen when magnesium sulphate is used to induce a cathartic effect similar to lactulose. ${ }^{22} 23$

The transit times of our subjects did not show any significant change with increase in faecal weight though faecal weights and mean transit times are generally inversely and exponentially related. ${ }^{24} 25$ The baseline mean faecal weights of our subjects are high and on the asymptotic phase of the curve ${ }^{26}$ and hence a further increase in faecal weight is therefore unlikely to decrease the mean transit times. Transit time also modifies the colonic response to diet. Increments in fibre intake increased faecal weight to a greater extent in those subjects who had the fastest transit time to begin with. ${ }^{27}$ Faecal excretion of cellulose varied with the transit time, being highest in individuals with the shortest transit time. ${ }^{28}$ It seems likely that with a short transit time, fibre metabolism is far from complete, and the undegraded fibre has a major role to play in faecal bulking. In high transit states, faecal bulk is low, ${ }^{25}$ and this is probably secondary to bacterial metabolism of fibre. It has also been shown that the degree of fibre degradation can be altered by changing the transit time. ${ }^{21}$ Metabolism of about $20 \mathrm{~g}$ dietary fibre per day yields around $200 \mathrm{mmol}$ of short chain fatty acids (SCFA's), ${ }^{29}$ the absorption of which is associated with a secondary absorption of water (100 mmol SCFA absorbed with $360 \mathrm{ml}$ water) and electrolytes. ${ }^{30}$ Degradation of fibre may thus contribute less to faecal bulking since the increment in faecal mass achieved by bacteria and bacterial water may be more than compensated by the loss of water secondary to SCFA absorption as well as reduction in the quantity of water holding fibre in the faeces.

Two mechanisms do exist to explain how dietary fibre bulks colonic contents and faeces and the predominance of one or the other depends on the type of dietary fibre and the extent to which it is degraded in the human colon. Water holding in vivo by undegraded fibre seems to be the more effective mechanism of faecal bulking than the role of bacterial mass consequent to bacterial degradation in low transit states. It may thus appear that the 
transit time of an individual may be the prime factor that determines faecal weight as well as colonic response to change in intake of dietary fibre, which may explain the low transits and high faecal weights reported from the tropics. ${ }^{26}$

This study was supported by the Medical Research Centre, Bombay Hospital Trust, Bombay. We would like to thank Dr J H Cummings, MRC Dunn Clinical Nutrition Centre for the supply of radioopaque markers.

\section{References}

1 Cummings JH, Hill MJ, Jenkins DJA, Pearson JR, Wiggins HS. Changes in faecal composition and colonic function due to cereal fibre. Am J Clin Nutr 1976; 29: 1468-73.

2 Eastwood MA. The role of vegetable dietary fibre in human nutrition. Med Hypoth 1975; 1: 46-53.

3 Stephen AM, Cummings JH. Water holding by dietary fibre in vitro and its relationship to faecal output in man. Gut 1979; 20: 722-9.

4 Stephen AM, Cummings JH. The microbial contribution to human faecal mass. J Med Microbiol 1980; 13: 45-56.

5 Stephen AM, Cummings JH. Mechanism of action of dietary fibre in the human colon. Nature 1980; 284: 283-4.

6 Shetty PS. Studies on protein and energy restriction and dietary thermogenesis in obesity and chronic undernutrition. University of Cambridge: PhD Thesis, 1980.

7 Gopalan C, Rama Sastri BV, Balasubramaniam SC. Nutritive value of Indian foods. New Delhi: ICMR 1980.

8 Paul AA, Southgate DAT. McCance and Widdowson's The composition of foods, 4th ed. London: HMSO, 1978.

9 Southgate DAT, Bailey B, Collinson E, Walker AF. A guide to calculating intakes of dietary fibre. J Hum Nutr 1976; 30: 303-13.

10 Wharton PA, Eaton PM, Day KC. Sorrento Asian food tables: food tables, recipes and customs of mothers attending Sorrento Maternity Hospital, Birmingham, England. Hum Nutr: Appl Nutr 1983; 37A: 378-402.

11 Goldring J, Scott A, McNaught W, Gillespie C. Prophylactic oral antimicrobial agents in elective colonic surgery: A controlled trial. Lancet 1975; 2: 997-9.

12 Cummings JH, Jenkins DJA, Wiggins HS. Measurement of the mean transit time of dietary residue through the human gut. Gut 1976; 17: 210-8.

13 Goering HK, Van Soest PJ. Forage fibre analyses. In: Agriculture Research Service. Agriculture Handbook, no 379. US Department of Agriculture 1970: 1-20.

14 Varley H, Gowenlock AH, Bell M. Practical clinical biochemistry, 5th ed. London: William Heinemann Medical Books Ltd, 1980.

15 Williams RD, Olmsted WH. The manner in which food controls the bulk of faeces. Ann Intern Med 1936; 10: 717-27.

16 Milton-Thompson GJ, Lewis B. The breakdown of dietary cellulose in man. [Abstract] Gut 1971; 12: A853-4.

17 Cummings JH. Polysaccharide fermentation in the human colon. In: Kasper $\mathrm{H}$, Goebell $\mathrm{H}$, eds. Colon and nutrition (Falk Symposium), Lancaster: MTP Press Ltd, 1982: 91-102.

18 Tabaqchali S. Ecology and metabolic activity of nonsporing anaerobes. In: Phillips $\mathrm{E}$, Sussman $\mathbf{R}$, eds. Infection with non-sporing anaerobic bacteria. Edinburgh: Churchill Livingstone, 1974: 59-90.

19 Cummings JH. Microbial digestion of complex carbohydrates in man. Proc Soc Nutr 1984; 43: 35-44.

20 Tally FP, Sutter VL, Finegold SM. Treatment of anaerobic infections with metronidazole. Antimicrob Agents Chemother 1975; 7: 672-5.

21 Stephen AM. Dietary fibre and human colonic function. University of Cambridge: PhD Thesis, 1980.

22 Weber FL. The effect of lactulose on urea metabolism and nitrogen excretion in cirrhotic patients. Gastroenterology 1979; 77: 518-23.

23 Weber FL, Fresard KM. Comparitive effects of lactulose and magnesium sulfate on urea metabolism and nitrogen excretion in cirrhotic subjects. Gastroenterology 1981; 80: 994-8.

24 Cummings JH. Diet and transit through the gut. $J \mathrm{Pl}$ Foods 1978; 3: 83-95.

25 Burkitt DP, Walker ARP, Painter NS. Effect of dietary fibre on stools and transit times, and its role in the causation of disease. Lancet 1972; 2: 1408-12.

26 Shetty PS, Kurpad AV. Intestinal transit time of South Indian subjects. Ind J Med Res 1984; 80: 693-8.

27 Cummings JH. Fibre metabolism in the large intestine. In: Vahouny GV, Kritchevsky D, eds. Dietary fibre in Health and Disease. New York: Plenum Press, 1982: 9-22.

28 Cummings JH, Southgate DAT, Branch WJ, et al. The digestion of pectin in the human gut and its effect on calcium absorption and large bowel function. $\mathrm{Br} J \mathrm{Nutr}$ 1979; 41: 477-85.

29 Cummings JH. Short chain fatty acids in the human colon. Gut 1981; 22: 763-79.

30 Caspary WF, Lembcke B, Elsehaus B. Bacterial fermentation of carbohydrates within the Gastrointestinal Tract. Clin Res Rev 1981; 1: suppl 1: 107-17. 